\title{
PENGARUH PENGENDALIAN INTERNAL DAN GAYA KEPEMIMPINAN \\ TERHADAP KINERJA KARYAWAN SPBU YOGYAKARTA \\ (STUDI KASUS PADA SPBU ANAK CABANG PERUSAHAAN RB.GROUP )
}

\author{
Sarita Permata Dewi \\ Thatharita@yahoo.com
}

\section{Fakultas Ekonomi Universitas Negeri Yogyakarta}

\begin{abstract}
Abstrak
Penelitian ini bertujuan (1) untuk mengetahui pengaruh Pengendalian Internal terhadap Kinerja Karyawan, (2) untuk mengetahui pengaruh Gaya Kepemimpinan terhadap Kinerja Karyawan (3) untuk mengetahui pengaruh Pengendalian Internal dan Gaya Kepemimpinan terhadap Kinerja Karyawan SPBU Anak Cabang Perusahaan RB. Group.

Berdasarkan permasalahannya penelitian ini merupakan penelitian ex-post facto dan berdasarkan tingkat penjelas kedudukan variabel penelitian ini merupakan penelitian kausal komparatif (CausalComparative Research) dengan unit analisis yang diteliti adalah karyawan yang terdapat pada SPBU Anak Cabang Perusahaan RB. Group. Penelitian ini termasuk penelitian populasi dengan jumlah populasi sebanyak 64 karyawan. Kuesioner di uji validitas dan reliabilitasnya sebelum melakukan pengumpulan data penelitian. Alat uji yang digunakan dalam penelitian ini menggunakan uji asumsi klasik yang meliputi uji heteroskedastisitas, uji multikolonieritas dan uji linearitas. Metode analisis data yang digunakan adalah analisis regresi sederhana dan analisis regresi berganda.

Hasil penelitian ini menunjukkan bahwa (1) Pengendalian Internal berpengaruh positif dan signifikan terhadap Kinerja Karyawan, yang ditunjukkan dengan nilai koefisien korelasi (R) sebesar 0,407, koefisien determinasi (R2) sebesar 0,165 dan nilai thitung $>$ ttabel pada taraf siginifikansi $5 \%$ yaitu 3,506 > 1,6698, (2) Gaya Kepemimpinan berpengaruh positif dan signifikan terhadap Kinerja Karyawan, yang ditunjukkan dengan nilai koefisien korelasi (R) sebesar 0,397, koefisien determinasi (R2) sebesar 0,158 dan nilai thitung $>$ ttabel pada taraf siginifikansi $5 \%$ yaitu $3,408>1.6698$, (3) Pengendalian Internal dan Gaya Kepemimpinan secara bersama-sama (simultan) berpengaruh positif dan signifikan terhadap Kinerja Karyawan, yang ditunjukkan dengan nilai koefisien korelasi (R) sebesar 0,481, koefisien determinasi (R2) sebesar 0,231 dan nilai Fhitung $>$ Ftabel pada taraf siginifikansi 5\% yaitu 9,180 > 3,1478.

Kata Kunci: Pengendalian Internal, Gaya Kepemimpinan, Kinerja Karyawan
\end{abstract}




\section{Jurnal Nominal / Volume I Nomor I / Tahun 2012}

\section{A. Pendahuluan}

\section{Latar Belakang Masalah}

Kinerja merupakan suatu fungsi kemampuan pekerja dalam menerima tujuan pekerjaan, tingkat pencapaian tujuan dan interaksi antara tujuan dan kemampuan pekerja menurut Judith R. Gordon dalam Hadari Nawawi (2006: 63). Dengan definisi tersebut dapat dikatakan bahwa karyawan memegang peranan penting dalam menjalankan segala aktivitas perusahaan agar dapat tumbuh berkembang mempertahankan kelangsungan hidup perusahaan. Untuk menciptakan sumber daya manusia yang handal membutuhkan pengelolaan yang baik agar Kinerja Karyawan lebih optimal. Pencapaian tujuan perusahaan dipengaruhi oleh Kinerja Karyawan perusahaan itu sendiri. Maka dari itu perusahaan membutuhkan sumber daya manusia yang berpotensial dan berkualitas, baik dari segi pemimpin maupun karyawan pada pola tugas, tanggung jawab, berdaya guna sesuai dengan peraturan dan pengawasan yang merupakan penentu tercapainya tujuan perusahaan.

Suatu perusahan yang telah berjalan sebaiknya memantau seluruh kegiatan operasionalnya. Sebuah pengendalian digunakan untuk membantu memantau kegiatan-kegiatan perusahaan. AICPA (American Institute of Certified Public accountants) dalam Wilopo (2006: 349) menjelaskan bahwa pengendalian internal sangat penting, antara lain untuk memberikan perlindungan bagi entitas terhadap kelemahan manusia serta untuk mengurangi kemungkinan kesalahan dan tindakan yang tidak sesuai dengan aturan. Pengelolaan dan penerapan pengendalian internal yang baik maka suatu perusahaan akan lebih mudah dalam pencapaian tujuannya.
Kinerja Karyawan dapat mengalami penurunan, hal seperti ini dapat terjadi dikarenakan adanya motivasi kerja di dalam diri mereka menurun dan adanya peluang-peluang untuk melakukan kecurangan. Pengimplementasian Pengendalian Internal yang baik pada semua struktur organisasi dalam perusahaan, maka dapat disediakan jaminan memadai mengenai prestasi dari sasaran kinerja dalam mengefektivitas dan mengefisiensikan operasional perusahaan, sehingga dalam laporan keuangan dapat memenuhi ketentuan hukum yang bisa diterapkan dan diregulasi. Jika Pengendalian Internal lemah maka akan mengakibatkan kekayaan perusahaan tidak terjamin keamanannya, informasi akuntansi yang ada tidak teliti dan tidak dapat dipercaya kebenarannya, tidak efisien dan efektifnya kegiatan-kegiatan operasional perusahaan serta tidak dapat dipatuhinya kebijakan yang telah ditetapkan.

Upaya-upaya dalam meningkatkan Kinerja Karyawan selain Pengendalian Internal, Gaya Kepemimpinan juga perlu diperhatikan. Seorang pemimpin yang ideal harus memiliki Gaya Kepemimpinan yang baik sehingga dapat meningkatkan kinerja karyawannya. Flippo (1994) dalam Nurjanah (2008: 39) berpendapat gaya kepemimpinan dapat dirumuskan sebagai suatu pola perilaku yang dirancang untuk memadukan kepentingankepentingan organisasi dan personalia guna mengejar beberapa sasaran. Gaya Kepemimpinan seorang pemimpin sangat diperlukan dalam suatu organisasi karena maju mundurnya suatu organisasi tergantung seberapa baik pemimpin dapat memainkan perannya agar organisasi tersebut terus hidup dan berkembang. Untuk itu seorang pemimpin sangat perlu memperhatikan gaya kepemimpinannya 


\section{Jurnal Nominal / Volume I Nomor I / Tahun 2012}

dalam proses mempengaruhi, mengarahkan kegiatan anggota kelompoknya serta mengkoordinasikan tujuan anggota dan tujuan organisasi agar keduanya dapat tercapai.

Gaya kepemimpinan yang baik adalah gaya kepemimpinan yang dapat memberikan motivasi kerja pada bawahannya. Ivancevich (2001) dalam Widyatmini dan Hakim (2008: 169) mengatakan seorang pemimpin harus menyatukan berbagai keahlian, pengalaman, kepribadian dan motivasi setiap individu yang dipimpinnya. Karyawan dapat memandang pimpinannya sebagai pemimpin yang efektif atau tidak, berdasarkan kepuasan yang mereka peroleh dari pengalaman kerja secara keseluruhan, sehingga diterimanya arahan atau permintaan pemimpin sebagian besar tergantung pada harapan pengikutnya (Eka Nuraini, 2004:68). Kinerja karyawan akan baik apabila pimpinan dapat memberi motivasi yang tepat dan pimpinan memiliki gaya kepemimpinan yang dapat diterima oleh seluruh karyawan dan mendukung terciptanya suasana kerja yang baik. Gaya kepemimpinan yang tidak efektif tidak akan memberikan pengarahan yang baik pada bawahannya terhadap usaha-usaha semua pekerjaan dalam mencapai tujuan-tujuan organisasi dalam perusahaan.

Kinerja karyawan di SBPU Anak Cabang Perusahaan RB.Group belum begitu maksimal misalnya tidak melakukan 3S (salam, sapa,dan senyum) yang merupakan standar kerja dari pertamina dan masih terdapat karyawan yang kurang disiplin dalam bekerja misalnya terlambat masuk kerja. Pada perusahaan SPBU belum dapat mengelola pengendalian internal dengan baik misalnya masih kurangnya pengawasan dari pimpinan SPBU secara langsung karena pemimpin tidak selalu berada di- perusahaan sehingga masih banyak ruang bagi karyawan untuk melakukan kecurangan dan pertukaran informasi yang berkaitan dengan kegiatan operasional perusahaan juga menjadi sedikit terhambat. Dengan adanya pemantauan dan aktivitas pengendalian oleh pemilik kepada pengelola, maka fungsi pengendalian internal semakin bertambah penting. Pimpinan SPBU terkadang juga kurang menyadari betapa pentingnya dan berpengaruhnya gaya kepemimpinan terhadap peningkatan kinerja karyawan misalnya pemimpin kurang memberikan motivasi dan kesempatan bagi karyawan untuk berpartisipasi dalam mengambil keputusan yang berkaitan dengan kegiatan operasional.

Pengendalian Internal dan Gaya kepemimpinan yang efektif dibutuhkan dalam suatu organisasi perusahaan untuk dapat meningkatkan kinerja semua karyawan dalam mencapai tujuan yang telah ditetapkan perusahaan. Berdasarkan latar belakang tersebut, maka mendorong penulis untuk melakukan penelitian dengan judul "Pengaruh Pengendalian Internal dan Gaya Kepemimpinan Terhadap Kinerja Karyawan SPBU di Yogyakarta (Studi Kasus Pada SBPU Anak Cabang Perusahaan RB.Group)"

\section{Kajian Literatur}

\section{1) Kinerja Karyawan}

\section{a. Pengertian Kinerja Karyawan}

Suyadi Prawirosentono (2008: 2) menyatakan Kinerja adalah hasil kerja yang dapat dicapai oleh seseorang atau kelompok orang dalam suatu organisasi sesuai dengan wewenang dan tanggung jawab masing-masing dalam rangka upaya mencapai tujuan organisasi bersangkutan secara legal tidak 


\section{Jurnal Nominal / Volume I Nomor I / Tahun 2012}

melanggar hukum dan sesuai dengan moral maupun etika. Muhammad Zainur (2010: 41) mendefinisikan "Kinerja merupakan keseluruhan proses bekerja dari individu yang hasilnya dapat digunakan landasan untuk menentukan apakah pekerjaan individu tersebut baik atau sebaliknya". Kinerja juga merupakan keluaran yang dihasilkan oleh fungsi-fungsi atau indikator suatu pekerjaan atau suatu profesi dalam waktu tertentu (Wirawan, 2009: 5).

Kamus besar bahasa Indonesia (2008: 629) mendefinisikan karyawan adalah orang yang bekerja pada suatu lembaga (kantor, perusahaan, dsb) dengan mendapat gaji atau upah. Malayu Hasibuan (2003: 12) mendefinisikan karyawan sebagai penjual jasa (pikiran dan tenaga) dan mendapatkan kompensasi yang besarnya telah ditetapkan terlebih dahulu.

\section{b. Faktor-faktor Kinerja Karyawan}

Menurut Dale Timple (2000) dalam Siti Munafiah (2011: 10-11) terdapat dua faktor yang mempengaruhi Kinerja Karyawan yaitu faktor internal dan faktor eksternal. Faktor internal adalah faktor-faktor yang berhubungan dengan sifat-sifat seseorang meliputi sikap, sifat kepribadian, sifat fisik, motivasi, umur, jenis kelamin, pendidikan, pengalaman kinerja, latar belakang budaya, dan variabel personal lainnya. Faktor eksternal adalah faktor-faktor yang mempengaruhi kinerja karyawan yang berasal dari lingkungan meliputi kebijakan organisasi, kepemimpinan, tindakantindakan rekan kerja, pengawasan, sistem upah, dan lingkungan sosial.

\section{c. Dimensi dan Indikator Kinerja Karyawan}

"Menurut Richard I. Handerson (1984) dalam
Wirawan (2009: 53) dimensi kinerja adalah kualitas-kualitas atau wajah suatu pekerjaan atau aktivitas-aktivas yang terjadi di tempat kerja yang konduktif terhadap pengukuran”. Dimensi kinerja menyediakan alat untuk melukiskan keseluruhan cakupan aktivitas di tempat kerja. Sementara itu, tanggung jawab dan kewajiban menyediakan suatu deskripsi depersonalisasi. Menurut Wirawan (2009: 54) dimensi kinerja dikelompokkan menjadi tiga jenis yaitu hasil kerja, perilaku kerja, dan sifat pribadi yang berhubungan dengan pekerjaan. Indikator-indikator kinerja karyawan menurut Chester I. Barnard dan Robert E. Quinn dalam Suyadi Prawirosentono (2008:27-32) adalah sebagai berikut:

\section{1) Efektivitas dan efisiensi}

Bila suatu tujuan tertentu akhirnya dapat dicapai, kita boleh mengatakan bahwa kegiatan tersebut efektif. Apabila akibat-akibat yang dicari dari kegiatan mempunyai nilai yang lebih penting dibandingkan hasil yang tercapai, sehingga mengakibatkan ketidakpuasan walaupun efektif, hal ini disebut tidak efisien. Sebaliknya jika akibat yang tidak dicari-cari tidak penting/remeh, maka kegiatan tersebut efisien. Sehubungan dengan itu kita dapat mengatakan sesuatu efektif bila mencapai tujuan tertentu. Dikatakan efisien bila hal itu memuaskan sebagai pendorong mencapai tujuan, terlepas apakah efektif atau tidak.

2) Otoritas dan tanggung jawab

Wewenang adalah hak seseorang untuk memberikan perintah (kepada bawahan), sedangkan tanggung jawab adalah bagian yang tidak terpisahkan atau sebagai akibat dari kepemilikan wewenang tersebut. Bila ada wewenang berarti dengan sendirinya muncul tanggung jawab. 


\section{Jurnal Nominal / Volume I Nomor I / Tahun 2012}

\section{3) Disiplin}

Disiplin meliputi ketaatan dan hormat terhadap perjanjian yang dibuat antara perusahaan dan karyawan. Disiplin juga berkaitan erat dengan sanksi yang perlu dijatuhkan kepada pihak yang melanggar.

\section{4) Inisiatif}

Inisiatif seseorang berkaitan dengan daya pikir, kreativitas dalam bentuk ide untuk merencanakan sesuatu yang berkaitan dengan tujuan organisasi

\section{2) Pengendalian Internal}

\section{a. Pengertian Pengendalian Internal}

Pengendalian internal menurut Committee of Sponsoring Organization of the Tread way Commission (Sawyer, 2005: 144) adalah proses, dipengaruhi oleh dewan entitas direksi, manajemen dan personel lain, yang dirancang untuk memberikan keyakinan memadai tentang pencapaian sasaran dalam kategori berikut:

1) Efektivitas dan efisiensi operasi.

2) Tingkat keandalan pelaporan keuangan.

3) Kepatuhan terhadap hukum dan peraturan yang berlaku.

Pengendalian intern adalah proses yang dirancang untuk memberikan kepastian yang layak mengenai pencapaian tujuan manajemen tentang reliabilitas pelaporan keuangan, efektivitas dan efisiensi operasi, dan kepatuhan terhadap hukum dan peraturan yang berlaku (Arens, 2006:412).

b. Komponen-komponen Pengendalian Internal Menurut Committee of Sponsoring Organization of the Tread way Commission (COSO) dalam Sawyer
(2005: 144) pengendalian internal satuan usaha terdiri atas komponen-komponen berikut:

1) Lingkungan pengendalian

Inti suatu bisnis adalah orang-orangnya dengan karakteristiknya termasuk integritas, nilai-nilai, etika dan lingkungan tempat mereka bekerja. Halhal tersebut merupakan mesin penggerak perusahaan dan merupakan fondasi segala sesuatunya ditempatkan.

\section{2) Penaksiran risiko}

Perusahaan harus mewaspadai dan mengelola risiko yang dihadapinya. Perusahaan harus menetapkan tujuan yang terintegrasi dengan penjualan, produksi, pemasaran, keuangan, dan aktivitasaktivitas lainnya sehingga organisasi beroperasi secara harmonis. Perusahaan juga harus menetapkan mekanisme untuk mengidentifikasi, menganalisis, dan mengelola risiko-risiko terkait.

3) Informasi dan komunikasi

Disekitar aktivitas-aktivitas ini terdapat sistem informasi dan komunikasi. Hal ini memungkinkan karyawan perusahaan mendapatkan dan menukar informasi yang diperlukan untuk melaksanakan, mengelola, dan mengendalikan operasinya.

4) Aktivitas pengendalian

Kebijakan dan prosedur kontrol harus ditetapkan dan dilaksanakan untuk membantu memastikan bahwa tindakan-tindakan yang diidentifikasi oleh manajamen diperlukan untuk menghadapi risiko terhadap pencapaian tujuan entitas secara efektif dilakukan.

\section{5) Pemantauan}

Keseluruhan proses harus dimonitor dan dibuat perubahan bila diperlukan. Dengan cara ini, sistem 


\section{Jurnal Nominal / Volume I Nomor I / Tahun 2012}

dapat bereaksi secara dinamis berubah seiring dengan perubahan kondisi. Pemantauan diakukan disetiap kegiatan operasional perusahaan.

c. Tujuan Pengendalian Internal

Tujuan Pengendalian Internal menurut Mulyadi (2002:180) adalah sebagai berikut :

1) Keandalan informasi keuangan

Pengendalian internal ini membuat manajemen bertanggung jawab menyiapkan laporan keuangan untuk kepentingan pihak intern dan ekstern perusahaan. Laporan yang disajikan harus dapat diandalkan.

2) Kepatuhan terhadap hukum dan peraturan yang berlaku

Pengendalian internal ini dimaksudkan agar organisasi melakukan kegiatannya sesuai dengan peraturan dan hukum yang berlaku.

3) Efektivitas dan efisiensi operasi

Pengendalian internal dalam perusahaan merupakan alat untuk mengurangi kegiatan pemborosan dan mengurangi penggunaan sumber daya yang tidak efektif dan efisien dalam operasi perusahaan.

d. Keterbatasan Bawaan dalam Pengendalian Intern Berikut ini adalah keterbatasan bawaan yang melekat dalam pengendalian internal menurut Mulyadi (2002: 181) yaitu: kesalahan dalam pertimbangan, gangguan, kolusi, dan pengabaian oleh manajemen.

\section{Gaya Kepemimpinan}

a. Pengertian Gaya Kepemimpinan

Miftah Thoha (2007: 49) menyatakan bahwa Gaya Kepemimpinan merupakan norma perilaku yang digunakan oleh seseorang pada saat orang tersebut mencoba mempengaruhi perilaku orang lain seperti yang ia lihat. Menurut Veithzal Rivai (2004: 64) Gaya kepemimpinan dapat didefenisikan sebagai perilaku dan strategi sebagai hasil kombinasi dari falsafah, keterampilan, sifat, dan sikap yang sering diterapkan seorang pemimpin ketika ia mencoba mempengaruhi kinerja bawahannya.

b. Fungsi Gaya Kepemimpinan

Fungsi Gaya Kepemimpinan memiliki hubungan langsung yang erat kaitanya dengan situasi sosial dalam kehidupan kelompok atau organisasi masing -masing yang mengisyaratkan bahwa setiap pemimpin berada di dalam situasi tersebut. Menurut Veithzal Rivai (2004: 53-56) terdapat lima fungsi pokok kepemimpinan, yaitu :

1) Fungsi Instruksi

Fungsi ini bersifat komunikasi satu arah. Pemimpin sebagai komunikator merupakan pihak yang menentukan apa, bagaimana, bilamana, dan dimana perintah itu dikerjakan agar keputusan dapat dilaksanakan secara efektif.

\section{2) Fungsi Konsultasi}

Fungsi ini bersifat komunikasi dua arah. Konsultasi itu dimaksudkan untuk memperoleh masukan berupa umpan balik untuk memperbaiki dan menyempurnakan keputusan-keputusan yang telah ditetapkan dan dilaksanakan.

\section{3) Fungsi Partisipasi}

Dalam menjalankan fungsi ini pemimpin berusaha mengaktifkan orang-orang yang dipimpinnya, baik dalam keikutsertaan mengambil keputusan maupun dalam melaksanakannya.

4) Fungsi Delegasi

Fungsi ini dilaksanakan dengan memberikan 


\section{Jurnal Nominal / Volume I Nomor I / Tahun 2012}

pelimpahan wewenang membuat atau menetapkan keputusan baik melalui persetujuan maupun tanpa persetuuan dari pemimpin.

\section{5) Fungsi Pengendalian}

Fungsi pengendalian bermaksud bahwa kepemimpinan yang sukses atau efektif mampu mengatur aktivitas anggotanya secara terarah dan dalam kooordinasi yang efektif sehingga memungkinkan tercapainya tujuan bersama secara maksimal.

\section{c. Macam-macam Gaya Kepemimpinan}

Teori Path Goal berusaha untuk menjelaskan pengaruh perilaku pemimpin terhadap motivasi, kepuasan, dan pelaksanaan pekerjaan bawahannya (Miftah Thoha, 2007: 42). Teori Path Goal membagi empat gaya kepemimpinan yaitu :

\section{1) Kepemimpinan direktif}

Tipe ini sama dengan model kepemimpinan otokratis bahwa bawahan tahu dengan pasti apa yang diharapkan darinya dan pengarahan yang khusus diberikan oleh pemimpin. Dalam model ini tidak ada partisipasi dari bawahannya.

\section{2) Kepemimpinan supportif}

Kepemimpinan ini mempunyai kesediaan untuk menjelaskan sendiri, bersahabay, mudah didekati, dan mempunyai perhatian kemanusiaan yang murni terhadap para bawahannya.

\section{3) Kepemimpinan partisipatif}

Pada gaya kepemimpinan ini pemimpin berusaha meminta dan menggunakan saran-saran dari para bawahannya. Namun pengambilan keputusan masih tetap berda padanya.

4) Kepemimpinan berorientasi pada prestasi

Gaya kepemimpinan ini menetapkan serangkaian tujuan yang menantang bawahannya untuk berpartisipasi. Pemimpin juga memberikan keyakinan kepada mereka bahwa mereka mampu melaksanakan tugas pekerjaan mencapai tujuan secara baik (Miftah Thoha, 2007: 42).

\section{Kerangka Berpikir}

1. Pengaruh Pengendalian Internal terhadap Kinerja Karyawan

Pengendalian Internal adalah segala sesuatu meliputi struktur organisasi, semua metode dan alat-alat yang dikoordinasikan yang digunakan dalam perusahaan dengan tujuan menjaga keamanan harta milik perusahaan, memeriksa ketelitian dan kebenaran data akuntansi, mendorong efisiensi, dan membantu mendorong dipatuhinya kebijakan manajemen yang telah ditetapkan. Komponenkomponen dalam Pengendalian Internal seperti lingkungan pengendalian yang baik, akan memberikan kontribusi baik dalam menciptakan suasana kerja sehingga dapat mendorong karyawan untuk meningkatkan kinerjanya. Perusahaan harus waspada terhadap segala resiko yang akan dihadapi dengan adanya penaksiran resiko maka karyawan dapat lebih meningkatkan kinerjanya dalam mengantisipasi mengatasi resiko-resiko yang mungkn terjadi. Informasi dan komunikasi akan memberikan dampak baik bagi peningkatan kinerja karena semua karyawan memperoleh dan bertukar informasi yang diperlukan dalam melakukan aktivitas operasional perusahaan. Aktivitas pengendalian akan mendorong karyawan menaati dan melaksanakan peraturan dan standar kerja yang sudah ditetapkan. Pemantauan yang baik akan membuat karyawan untuk lebih disiplin dalam bekerja. 


\section{Jurnal Nominal / Volume I Nomor I / Tahun 2012}

H1 : Pengendalian Internal berpengaruh positif terhadap Kinerja Karyawan SPBU di Yogyakarta.

2. Pengaruh Gaya Kepemimpinan terhadap Kinerja Karyawan

Kinerja Karyawan juga dapat dipengaruhi oleh Gaya kepemimpinan yang dianut dan diterapkan oleh manajemen puncak atau pimpinan. Teori path Goal mengansumsikan bahwa pimpinan bisa mengubah gaya atau perilaku mereka untuk memenuhi permintaan dari situasi tertentu, misalnya saat menghadapi kelompok bawahan baru atau proyek baru, pemimpin mungkin berprilaku direktif dalam membuat prosedur kerja dan menjelaskan apa yang mesti dilakukan. Berikutnya, pemimpin dapat menggunakan perilaku suportif untuk meningkatkan kepaduan kelompok dan menumbuhkan iklim positif. Setelah kelompok familier dengan tugas dan saat masalah-masalah baru ditemukan, pemimpin dapat menampakkan perilaku partisipatif untuk meningkatkan motivasi anggota kelompok. Terakhir, perilaku yang berorientasi pada prestasi dapat dipakai untuk mendorong kinerja yang semakin meningkat. Penerapan Gaya Kepemimpinan yang sesuai dengan karakter karyawan, pekerjaan, dan kondisi yang ada dapat memberikan kontribusi yang besar terhadap peningkatan Kinerja Karyawan.

H2 : Gaya Kepemimpinan berpengaruh positif terhadap Kinerja Karyawan SPBU di Yogyakarta.

3. Pengaruh Pengendalian Internal dan Gaya Kepemimpinan terhadap Kinerja Karyawan

Kinerja karyawan merupakan hasil kerja yang dapat dicapai seseorang atau sekelompok orang dalam suatu organisasi sesuai wewenang dan tanggung jawab masing-masing dalam rangka un- tuk mewujudkan tujuan perusahaan. Komponenkomponen Pengendalian Internal seperti lingkungan pengendalian, penaksiran resiko, informasi dan komunikasi, aktivitas pengendalian, dan pemantauan yang baik akan mendorong kinerja karyawan untuk lebih disiplin dan bertanggung jawab. Terdapat empat macam Gaya Kepemimpinan yaitu partisipatif, direktif, suportif, dan berorientasi pada prestasi dalam Teori Path Goal yang mengansumsikan bahwa pimpinan bisa mengubah gaya mereka untuk memenuhi permintaan dari situasi tertentu. Pengendalian internal dan gaya kepemimpinan yang diterapkan dalam suatu perusahaan harus sangat diperhatikan. Apabila kedua faktor tersebut diimplementasikan dengan baik maka karyawan dapat bekerja secara maksimal dan berusaha untuk meningkatkan kinerjanya.

H3 : Pengendalian Internal dan Gaya Kepemimpinan secara bersama-sama berpengaruh positif terhadap Kinerja Karyawan SPBU di Yogyakarta.

\section{B. Metode Penelitian}

\section{Populasi}

Populasi dalam penelitian ini yaitu karyawan yang bekerja di SPBU anak cabang perusahaan RB. Group Yogyakarta yaitu SPBU 44.55208 Monjali dan SPBU 44.55706 Bantul yang secara keseluruhan berjumlah 64 karyawan.

\section{Jenis Penelitian}

Berdasarkan permasalahannya penelitian ini digolongkan penelitian ex-post facto. Ex-post facto yaitu tipe penelitian terhadap data yang dikumpulkan setelah terjadinya suatu fakta atau peristiwa. Berdasarkan tingkat penjelasan kedudukan variabel, penelitian ini digolongkan dalam penelitian kausal 
Jurnal Nominal / Volume I Nomor I / Tahun 2012

komparatif. Penelitian kausal komparatif merupakan 9

penelitian dengan karakteristik masalah berupa sebab akibat anatara dua variabel atau lebih (Nur Indriantoro dan Bambang Supomo, 2009: 27).

\section{Definisi Operasional}

a. Variabel Dependen (Kinerja Karyawan)

Kinerja Karyawan adalah hasil kerja yang dapat dicapai oleh seseorang atau kelompok orang dalam suatu organisasi sesuai dengan wewenang dan tanggungjawab masing-masing dalam mencapai tujuan organisasi sesuai dengan peraturan yang telah ditetapkan dan tidak melanggar hukum. Indikator-indikator penilaian kinerja yaitu: Efektivitas dan efisiensi, Otoritas dan tanggung jawab, Disiplin, dan Inisiatif (Chester I. Barnard dan Robert E. Quinn dalam Suyadi Prawirosentono (2008: 27-32)).

\section{b. Variabel Independen \\ 1) Pengendalian Internal}

Pengendalian internal adalah sistem yang meliputi struktur organisasi, semua metode dan ketentuanketentuan yang terkoordinasi yang dianut dalam perusahaan untuk melindungi harta kekayaan, memeriksa ketelitian, dan seberapa jauh data akuntansi dapat dipercaya, meningkatkan efisiensi usaha dan mendorong ditaatinya kebijakan perusahaan yang telah ditetapkan. Pengendalian internal terdiri atas komponen-komponen berikut: Lingkungan pengendalian, Penaksiran risiko, Informasi dan komunikasi, Aktivitas pengendalian, dan Pemantauan (Committee of Sponsoring Organization of the Tread way Commission (COSO) dalam Sawyer (2005: 144)).
2) Gaya Kepemimpinan

Gaya Kepemimpinan merupakan perilaku atau cara yang digunakan oleh seseorang pemimpin pada saat ia mempengaruhi perilaku bawahanya dalam bekerja. Indikator gaya kepemimpinan yaitu: Partisipatif, Direktif, Supportif, dan Berorientasi pada prestasi (Miftah Thoha (2007: 42)).

\section{Teknik Pengumpulan Data}

Kuesioner (angket) merupakan teknik pengumpulan data yang dilakukan dengan cara memberi seperangkat pertanyaan atau pernyataan tertulis kepada responden untuk dijawab (Sugiyono, 2009:142). Kuesioner ini terdiri dari butir-butir pertanyaan atau pernyataan dengan variabel dependen Kinerja Karyawan dan variabel indenpenden Pengendalian Internal dan Gaya Kepemimpinan. Kuesioner diberikan kepada responden untuk mengetahui pengaruh Pengendalian Intern dan Gaya Kepemimpinan terhadap Kinerja Karyawan di SPBU anak cabang perusahaan RB. Group Yogyakarta.

\section{Teknik Analisis Data}

\section{Uji Asumsi Klasik}

a. Uji Heteroskedatisitas

Uji Heteroskedastisitas bertujuan untuk menguji apakah dalam model regresi terjadi ketidaksamaan variance dari residual satu pengamatan ke pengamatan yang lain. Jika variance dari residual satu pengamatan ke pengamatan lain tetap maka disebut homokedastisitas dan jika berbeda disebut heteroskedastisitas. Uji heteroskedastisitas 


\section{Jurnal Nominal / Volume I Nomor I / Tahun 2012}

menggunakan metode uji glejser yang mengusulkan untuk meregres nilai absolut residual terhadap variabel independen. Jika variabel independen secara signifikan secara statistik tidak mempengaruhi variabel dependen, maka tidak terdapat indikasi terjadi heteroskedastisitas. Hal ini dapat dilihat apabila dari probabilitas signifikansinya di atas tingkat kepercayaan 5\% (Imam Ghozali, 2009: 129).

\section{b. Uji Multikolinearitas}

Uji multikolinieritas bertujuan untuk menguji apakah dalam model regresi ditemukan adanya korelasi antar variabel bebas (independen). Untuk mendeteksi ada atau tidaknya multikolinearitas maka dilakukan dengan melihat nilai Tolerance Value dan Variance Inflation Factor (VIF). Tolerance Value mengukur variabilitas variabel independen yang terpilih yang tidak dijelaskan oleh variabel independen lainnya. Jadi, nilai tolerance yang rendah sama dengan nilai VIF tinggi karena $\mathrm{VIF}=1 /$ Tolerance Value). Nilai yang umum dipakai untuk menunjukkan adanya mulitkolonieritas adalah nilai Tolerance Value $\leq 0,01$ atau sama dengan nilai VIF $\geq 10$ maka tidak terjadi multikolineritas antara variabel independennya (Imam Ghozali, 2009: 96).

\section{c. Uji Linearitas}

Uji linieritas digunakan untuk mengetahui hubungan antara variabel bebas dan variabel terikat bersifat linier atau tidak. Pengujian ini menggunakan uji $\mathrm{F}$ dengan rumus sebagai berikut:

$$
F_{\text {reg }}=\frac{R K_{\text {reg }}}{R K_{\text {res }}}
$$

Keterangan:

: Harga bilangan F untuk garis regresi

: Rerata kuadrat garis regresi

: Rerata kuadrat residu

(Sutrisno Hadi, 2004:13)

Kriteria yang digunakan yaitu regresi dikatakan linier jika Fhitung < Ftabel, selain itu data dapat dikatakan linier jika nilai signifikansi lebih besar dari alpha yang ditentukan yaitu 5\% (Imam Ghozali, 2009: 154).

\section{Uji Hipotesis}

\section{a. Analisis Regresi Linear Sederhana}

Regresi sederhana didasarkan pada hubungan fungsional ataupun kausal satu variabel independen dengan satu variabel dependen. Analisis ini digunakan untuk mengetahui bagaimana pengaruh variabel independen (X1) dan (X2) terhadap variabel dependen (Y). Berikut adalah langkah-langkah dalam analisis regresi sederhana:

1) Membuat garis regresi sederhana

$\mathrm{Y}=\mathrm{a}+\mathrm{bX}$

Keterangan :

Y : subjek dalam variabel dependen yang diprediksi.

$\mathrm{a}$ : harga $\mathrm{Y}$, bila $\mathrm{x}=0$ (harga konstanta).

$\mathrm{b}$ : angka arah/koefisien regresi yang menunjukkan peningkatan atau penurunan variabel dependen. Apabila $\mathrm{b}$ positif $(+)=$ naik dan bila $\mathrm{b}$ minus $(-)=$ turun.

$X$ : subjek pada variabel independen yang mempunyai nilai tertentu.

(Sugiyono, 2009: 188) 
2) Mencari kofisien determinasi (r2) antara prediktor X1 dengan $\mathrm{Y}$ dan prediktor $\mathrm{X} 2$ dengan $\mathrm{Y}$

$$
\begin{aligned}
& r_{(x 1 y)}^{2}=\frac{a_{1} \sum X_{1} Y}{\sum Y^{2}} \\
& r_{(x 2 y)}^{2}=\frac{a_{2} \sum X_{2} Y}{\sum Y^{2}}
\end{aligned}
$$

Keterangan:

$\mathrm{r} 2(\mathrm{x} 1 \mathrm{y})=$ Koefisien determinasi antara $\mathrm{X} 1$ dengan $\mathrm{Y}$

$\mathrm{r} 2(\mathrm{x} 2 \mathrm{y})=$ Koefisien determinasi antara X2 dengan $\mathrm{Y}$

a1 = Koefisien prediktor X1

a2 $=$ Koefisien prediktor X2

$\Sigma \mathrm{X} 1 \mathrm{Y}=$ Jumlah produk $\mathrm{X} 1$ dengan $\mathrm{Y}$

$\Sigma \mathrm{X} 2 \mathrm{Y}=$ Jumlah produk $\mathrm{X} 2$ dengan $\mathrm{Y}$

$\sum \mathrm{Y} 2=$ Jumlah kuadrat kriterium $\mathrm{Y}$

(Sutrisno Hadi, 2004: 22)

3) Menguji signifikansi dengan uji t

Menguji koefisien garis regresi digunakan uji statistik t. Uji t dilakukan untuk menguji signifikansi konstanta tiap variabel independen akan berpengaruh terhadap variabel dependen dengan rumus sebagai $t=\frac{r \overline{n-2}}{\overline{1-} r^{2}}$ berikut:

Keterangan:

$\mathrm{t}$ : thitung

$\mathrm{r}$ : koefisien korelasi $\mathrm{n}$ : jumlah ke-n

(Sugiyono,2009: 184)

Uji statistik t pada dasarnya menunjukan seberapa jauh pengaruh variabel independen secara individual dalam mnerangkan variasi variabel dependen. Dalam mengambil keputusan dilakukan dengan membandingkan nilai antara thitung dan ttabel dengan taraf sinifikansi 5\%. Apabila nilai statistik t lebih tinggi dibandingkan nilai ttabel, maka variabel independen secara individual memiliki pengaruh yang signifikan terhadap variabel dependen (Imam Ghozali, 2009: 88-89).

b. Analisis Regresi Linear Berganda

Analisis regresi berganda digunakan untuk memprediksi pengaruh dua variabel bebas atau lebih terdapat satu variabel terikat. Lngkah-langkah dalam analisis regresi berganda adalah sebagai berikut:

1) Membuat persamaan garis regresi dua prediktor dengan rumus sebagai berikut:

$\mathrm{Y}=\mathrm{a} 1 \mathrm{X} 1+\mathrm{a} 2 \mathrm{X} 2+\mathrm{K}$

Keterangan:

$\mathrm{Y}=$ Kriterium

$\mathrm{X} 1=$ Prediktor 1

$\mathrm{X} 2=$ Prediktor 2

a1 = Bilangan koefisen prediktor X1

a2 = Bilangan koefisien prediktor X2

$\mathrm{K}=$ Bilangan konstanta

(Sutrisno Hadi, 2004:18)

2) Mencari koefisien determinasi (R2) antara prediktor X1 dan X2 dengan kriterium Y, 


\section{$\mathrm{R}_{\mathrm{y}(\mathrm{x} 1 \mathrm{x} 2)}^{2}=\frac{\mathrm{a}_{1} \sum \mathrm{X}_{1} \mathrm{Y}+\mathrm{a}_{2} \sum \mathrm{X}_{2} \mathrm{Y}}{\sum \mathrm{Y}^{2}}$}

menggunakan rumus:

Keterangan:

$\mathrm{R} 2 \mathrm{y}(\mathrm{x} 1 \mathrm{x} 2)=$ Koefisien determinasi antara $\mathrm{Y}$ dengan $\mathrm{X} 1$ dan $\mathrm{X} 2$

a1 = koefisien prediktor X1

$\mathrm{a} 2=$ koefisien prediktor $\mathrm{X} 2$

$\sum \mathrm{X} 1 \mathrm{Y}=$ Jumlah produk $\mathrm{X} 1$ dengan $\mathrm{Y}$

$\sum \mathrm{X} 2 \mathrm{Y}=$ Jumlah produk $\mathrm{X} 2$ dengan $\mathrm{Y}$

$\sum \mathrm{Y} 2=$ Jumlah kuadrat kriterium $\mathrm{Y}$

(Sutrisno Hadi, 2004: 22)

Koefisien determinasi (R2) merupakan proporsi atau persentase dari total variasi Y yang dijelaskan oleh garis regresi. Koefisien determinasi adalah kuadrat koefisien korelasi. Koefisien determinasi ini digunakan untuk mengetahui presentasi pengaruh yang terjadi dari variabel bebas terhadap variabel terikat.

$$
\begin{aligned}
& 3 \text { ) } \\
& \mathrm{F}_{\mathrm{reg}}=\frac{\mathrm{R}^{2} \mathrm{~N}-\mathrm{m}-1}{\mathrm{~m} 1-\mathrm{R}^{2}} \begin{array}{c}
\text { M e } \mathrm{ng} \mathrm{u} \mathrm{j} \mathrm{i} \\
\text { keberartian } \\
\text { gresi ganda, }
\end{array}
\end{aligned}
$$
dengan rumus:
$\mathrm{M}=$ Cacah prediktor

$\mathrm{R} 2=$ Koefisien determinasi antara kriterium dengan prediktor- prediktor

(Sutrisno Hadi, 2004: 23)

Pengujian ini pada dasarnya menunjukkan apakah semua variabel independen yang dimasukkan dalam model mempunyai pengaruh secara bersamasama terhadap variabel dependen. Setelah diperoleh perhitungan, kemudian Fhitung dikonsultasikan dengan Ftabel pada taraf signifikansi 5\%. Apabila harga Fhitung $\geq$ harga Ftabel berarti seluruh variabel independen secara bersama-sama berpengaruh signifikan terhadap variabel dependen. Apabila Fhitung < Ftabel berarti seluruh variabel independen secara bersama-sama tidak berpengaruh signifikan terhadap variabel dependen.

4) Mencari besarnya sumbangan setiap variabel prediktor terhadap kriterium

a. Sumbangan Relatif (SR\%)

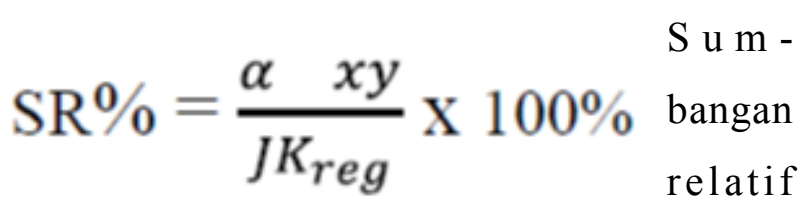
digunakan untuk mencari perbandingan relatifitas yang diberikan suatu variabel bebas kepada variabel terikat dengan variabel bebas lain yang diteliti. Sumbangan Relatif dapat dihitung dengan rumus :
Keterangan :

Keterangan:

$F=$ Harga $F$ regresi

$\mathrm{N}=$ Cacah kasus
SR \% : sumbangan relatif dari suatu prediktor 13

a : koefisien prediktor

$\mathrm{xy}$ : jumlah produk antara $\mathrm{X}$ dan $\mathrm{Y}$ 
JKreg : jumlah kuadrat regresi

(Sutrisno Hadi, 2004: 37)

b. Sumbangan Efektif (SE\%)

Sumbangan efektif digunakan untuk mengetahui besarnya sumbangan secara efektif setiap prediktor terhadap kriterium dengan tetap mempertimbangkan variabel bebas lain yang tidak diteliti. Efektivitas regresi dicerminkan dalam koefisien determinasi (R)2 maka SE\% tiap prediktor dapat dihitung langsung dari R2 dengan rumus sebagai berikut:

\section{Hasil Penelitian, Pembahasan, dan Keterbatasan Penelitian}

Tabel 1. Statistik Deskriptif Data

\section{Statistics}

\begin{tabular}{|c|c|c|c|c|}
\hline & & $\begin{array}{c}\text { Pengendalian } \\
\text { Internal }\end{array}$ & $\begin{array}{c}\text { Gaya } \\
\text { Kepemimpinan }\end{array}$ & $\begin{array}{c}\text { Kinerja } \\
\text { Karyawan }\end{array}$ \\
\hline $\mathrm{N}$ & Valid & 64 & 64 & 64 \\
\hline & Missing & 0 & 0 & 0 \\
\hline Mean & & 49.3438 & 42.9844 & 64.0625 \\
\hline Median & & 49.0000 & 43.0000 & 63.0000 \\
\hline Mode & & $48.00^{\mathrm{a}}$ & 42.00 & 63.00 \\
\hline Std. Deviati & & 1.70171 & 1.76826 & 2.23873 \\
\hline Variance & & 2.896 & 3.127 & 5.012 \\
\hline Skewness & & .456 & .327 & .401 \\
\hline Std. Error of & ness & .299 & .299 & .299 \\
\hline Kurtosis & & 1.355 & -.792 & -.938 \\
\hline Std. Error of & & .590 & .590 & .590 \\
\hline Range & & 10.00 & 7.00 & 8.00 \\
\hline Minimum & & 44.00 & 40.00 & 60.00 \\
\hline Maximum & & 54.00 & 47.00 & 68.00 \\
\hline Percentiles & 25 & 48.0000 & 42.0000 & 63.0000 \\
\hline & 50 & 49.0000 & 43.0000 & 63.0000 \\
\hline & 75 & 50.0000 & 45.0000 & 66.0000 \\
\hline
\end{tabular}

Berdasarkan hasil tabel statistik deskripsi data di atas terdapat 3 variabel yaitu variabel Kinerja Karyawan, Pengendalian Internal, dan Gaya Kepemimpinan. Pada tabel di atas variabel Kinerja Karya- wan menunjukkan bahwa nilai terkecil (minimum) adalah 60,00, nilai terbesar (maximum) adalah 68,00 dan nilai rata-rata sebesar 64,062 . Variabel Pengendalian Internal menunjukkan nilai terkecil 
Jurnal Nominal / Volume I Nomor I / Tahun 2012

(minimum) adalah 44,00, nilai terbesar (maximum) adalah 54,00 dan nilai rata-rata sebesar 49,34. Variabel Gaya Kepemimpinan menunjukkan nilai terkecil (minimum) adalah 40,00, nilai terbesar (maximum) adalah 47,00 dan nilai rata-rata sebesar 42,98 .

\section{Uji Heteroskedastisitas}

Tabel 2. Rangkuman Hasil Uji Heteroskedastisitas

\begin{tabular}{|c|r|r|r|r|r|}
\hline \multirow{2}{*}{ Model } & \multicolumn{2}{|c|}{$\begin{array}{c}\text { Unstandardized } \\
\text { Coefficients }\end{array}$} & $\begin{array}{c}\text { Standardized } \\
\text { Coefficients }\end{array}$ & \multirow{2}{*}{$\mathrm{t}$} & \multirow{2}{*}{ Sig } \\
\cline { 2 - 4 } & \multicolumn{1}{|c|}{$\mathrm{B}$} & Std. Error & \multicolumn{1}{c|}{ Beta } & & \\
\hline 1 (Constant) & .913 & 4.838 & & .189 & .851 \\
$\mathrm{X}_{1}$ & -.030 & .096 & -.043 & -.310 & .757 \\
$\mathrm{X}_{2}$ & .049 & .093 & .074 & .532 & .597 \\
\hline
\end{tabular}

Dari tabel di atas dapat diketahui bahwa signifikansi semua variabel lebih besar dari 0,05, sehingga dapat disimpulkan bahwa dalam model regresi ini tidak terjadi heteroskedastisitas.

\section{Uji Multikoloniearitas}

Tabel 3. Rangkuman Hasil Uji Multikolinearitas

\begin{tabular}{|c|c|c|c|c|c|c|c|}
\hline \multirow[t]{2}{*}{ Model } & \multicolumn{2}{|c|}{$\begin{array}{c}\text { Unstandardized } \\
\text { Coefficients }\end{array}$} & \multirow{2}{*}{$\begin{array}{c}\text { Standardized } \\
\text { Coefficients } \\
\text { Beta }\end{array}$} & \multirow[t]{2}{*}{$t$} & \multirow[t]{2}{*}{ Sig. } & \multicolumn{2}{|c|}{$\begin{array}{l}\text { Collinearity } \\
\text { Statistics }\end{array}$} \\
\hline & B & Std. Error & & & & Tolerance & VIF \\
\hline 1 (Constant) & 29.652 & 8.088 & & 3.666 & .001 & & \\
\hline $\mathrm{X} 1$ & .389 & .161 & .296 & 2.416 & .019 & .842 & 1.188 \\
\hline $\mathrm{X} 2$ & .354 & .155 & .280 & 2.287 & .026 & .842 & 1.188 \\
\hline
\end{tabular}

Hasil uji multikolonieritas antar variabel bebas menunjukkan bahwa interkorelasi antar variabel bebas nilai Tolerance di atas 0,1 dan VIF $<10$ maka dapat disimpulkan bahwa tidak terjadi multikolonieritas antar variabel sehingga regresi ganda dapat dilanjutkan.

\section{Uji Linieritas}

Tabel 4. Rangkuman Hasil Uji Linearitas

\begin{tabular}{|c|c|c|}
\hline Korelasi & Deviation from Linearity & Kriteria \\
\hline $\mathrm{X}_{1}$ dengan $\mathrm{Y}$ & 0,766 & Linear \\
\hline $\mathrm{X}_{2}$ dengan $\mathrm{Y}$ & 0,060 & Linear \\
\hline
\end{tabular}

Berdasarkan tabel di atas terlihat bagi signifikansi

dari dua korelasi di atas lebih besar dari 0,05 maka 
Jurnal Nominal / Volume I Nomor I / Tahun 2012

dapat dikatakan bahwa hubungan masing-masing hingga uji regresi dapat dilanjutkan.

variabel bebas dan variabel terikatnya linear, se-

\section{Uji Hipotesis}

1) Uji Hipotesis Pertama (Pengendalian Internal berpengaruh positif terhadap Kinerja Karyawan)

Tabel 5. Model Summary Hasil Analisis Regresi Linier Sederhana Pengendalian Internal terhadap Kinerja Karyawan

\begin{tabular}{|l|r|r|r|r|}
\hline Model & \multicolumn{1}{|c|}{$\mathrm{R}$} & R Square & \multicolumn{1}{c|}{$\begin{array}{c}\text { Adjusted R } \\
\text { Square }\end{array}$} & $\begin{array}{c}\text { Std. Error of the } \\
\text { Estimate }\end{array}$ \\
\hline 1 & $.407^{\mathrm{a}}$ & .165 & .152 & 2.06159 \\
\hline
\end{tabular}

Tabel 6. Model Coefficients Hasil Analisis Regresi Linier Sederhana Pengendalian Internal terhadap Kinerja Karyawan

\begin{tabular}{|l|r|r|r|r|r|}
\hline & \multicolumn{2}{|c|}{$\begin{array}{c}\text { Unstandardized } \\
\text { Coefficients }\end{array}$} & $\begin{array}{c}\text { Standardized } \\
\text { Coefficients }\end{array}$ & & \\
\cline { 2 - 5 } Model & \multicolumn{1}{|c|}{$\mathrm{B}$} & Std. Error & Beta & \multicolumn{1}{c|}{$\mathrm{t}$} & \multicolumn{1}{c|}{ Sig. } \\
\hline 1 (Constant) & 42.446 & 6.348 & & 6.686 & .000 \\
$\mathrm{X} 2$ & .503 & .148 & .397 & 3.408 & .001 \\
\hline
\end{tabular}

2) Uji Hipotesis Kedua (Gaya Kepemimpinan berpengaruh positif Terhadap Kinerja Karyawan)

Tabel 7. Model Summary Hasil Analisis Regresi Linier Sederhana Gaya Kepemimpinan terhadap Kinerja Karyawan

\begin{tabular}{|l|r|r|r|r|}
\hline Model & \multicolumn{1}{|c|}{$\mathrm{R}$} & R Square & \multicolumn{1}{c|}{$\begin{array}{c}\text { Adjusted R } \\
\text { Square }\end{array}$} & $\begin{array}{c}\text { Std. Error of the } \\
\text { Estimate }\end{array}$ \\
\hline 1 & $.397^{\mathrm{a}}$ & .158 & .144 & 2.07104 \\
\hline
\end{tabular}

Tabel 8. Model Coefficients Hasil Analisis Regresi Linier Sederhana Gaya Kepemimpinan terhadap Kinerja Karyawan

\begin{tabular}{|c|c|c|c|c|c|}
\hline \multirow[b]{2}{*}{ Model } & \multicolumn{2}{|c|}{$\begin{array}{c}\text { Unstandardized } \\
\text { Coefficients }\end{array}$} & \multirow{2}{*}{ 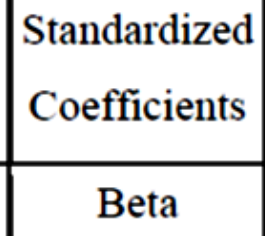 } & \multirow[b]{2}{*}{$\mathrm{t}$} & \multirow[b]{2}{*}{ Sig. } \\
\hline & B & Std. Error & & & \\
\hline $1 \quad$ (Constant) & 37.658 & 7.536 & & 4.997 & .000 \\
\hline $\mathrm{X} 1$ & .535 & .153 & .407 & 3.506 & .001 \\
\hline
\end{tabular}


Jurnal Nominal / Volume I Nomor I / Tahun 2012

3) Uji Hipotesis Ketiga (Pengendalian Internal dan Gaya Kepemimpinan secara bersama-sama berpengaruh positif terhadap Kinerja Karyawan)

Tabel 9. Model Summary Hasil Analisis Regresi Linier berganda Pengendalian Internal dan Gaya Kepemimpinan terhadap Kinerja Karyawan

Model Summary

\begin{tabular}{|l|r|r|r|c|}
\hline Model & \multicolumn{1}{|c|}{$\mathrm{R}$} & R Square & \multicolumn{1}{c|}{$\begin{array}{c}\text { Adjusted R } \\
\text { Square }\end{array}$} & $\begin{array}{l}\text { Std. Error of the } \\
\text { Estimate }\end{array}$ \\
\hline 1 & $.481^{\mathrm{a}}$ & .231 & .206 & 1.99468 \\
\hline
\end{tabular}

Tabel 10. Anova Hasil Analisis Regresi Linier berganda Pengendalian Internal dan Gaya Kepemimpinan terhadap Kinerja Karyawan

ANOVA $^{\text {b }}$

\begin{tabular}{|c|c|c|c|c|c|c|}
\hline \multicolumn{2}{|c|}{ Model } & Sum of Squares & df & Mean Square & $F$ & Sig. \\
\hline 1 & Regression & 73.046 & 2 & 36.523 & 9.180 & $.000^{3}$ \\
\hline & Residual & 242.704 & 61 & 3.979 & & \\
\hline & Total & 315.750 & 63 & & & \\
\hline
\end{tabular}

Tabel 11. Model Coefficients Hasil Analisis Regresi Linier Berganda Pengendalian Internal dan Gaya Kepemimpinan terhadap Kinerja Karyawan

\begin{tabular}{|c|c|c|c|c|c|c|c|c|}
\hline \multicolumn{9}{|c|}{ Coefficients $^{a}$} \\
\hline \multirow{2}{*}{\multicolumn{2}{|c|}{ Model }} & \multicolumn{2}{|c|}{$\begin{array}{c}\text { Unstandardized } \\
\text { Coefficients }\end{array}$} & \multirow{2}{*}{\begin{tabular}{|c|}
$\begin{array}{c}\text { Standardized } \\
\text { Coefficients }\end{array}$ \\
Beta \\
\end{tabular}} & \multirow[b]{2}{*}{$t$} & \multirow[b]{2}{*}{ Sig. } & \multicolumn{2}{|c|}{$\begin{array}{c}95.0 \% \text { Confidence Interval } \\
\text { for B }\end{array}$} \\
\hline & & B & Std. Error & & & & Lower Bound & Upper Bound \\
\hline 1 & (Constant) & 29.652 & 8.088 & & 3.666 & .001 & 13.478 & 45.825 \\
\hline & $\mathrm{X} 1$ & .389 & .161 & .296 & 2.416 & .019 & .067 & .71 \\
\hline & $\mathrm{X} 2$ & .354 & .155 & .280 & 2.287 & .026 & .044 & .66 \\
\hline
\end{tabular}

Pembahasan

1. Pengendalian Internal Berpengaruh terhadap Kinerja Karyawan

Hasil penelitian mendukung hipotesis pertama yaitu Pengendalian Internal berpengaruh positif terhadap Kinerja karyawan SPBU Yogyakarta. Hal ini ditunjukkan dari hasil analisis regresi Pengendalian Internal (X1) terhadap Kinerja Karyawan (Y) diperoleh suatu persamaan regresi 1 prediktor yaitu $\mathrm{Y}=37,658+0,535 \mathrm{X} 1$ yang menyatakan jika nilai Pengendalian Internal (X1) nol maka nilai Kinerja Karyawan (Y) adalah sebesar 37,658 dan setiap kenaikan Pengendalian Internal (X1) 1 satuan maka akan menaikkan Kinerja Karyawan (Y) sebesar 0,535 satuan, selain itu dapat juga dilihat dari nilai korelasi regresi (R) yang bernilai positif antara Pengendalian Internal (X1) dan Kinerja Karyawan (Y) sebesar 0,407. Nilai thitung lebih besar 


\section{Jurnal Nominal / Volume I Nomor I / Tahun 2012}

dari nilai ttabel yaitu 3,506>1,6698 dengan nilai sig 0,001 (di bawah 0,05) yang mengidentifikasikan bahwa variabel Pengendalian Internal (X1) berpengaruh signifikan terhadap Kinerja Karyawan (Y). Dari hasil analisis regresi sederhana juga diperoleh nilai koefisien determinasi (R2) sebesar 0,165 yang berarti $16,5 \%$ naik turunnya nilai Kinerja Karyawan dipengaruhi oleh Pengendalian Internal, sedangkan sisanya sebesar 83,5\% dipengaruhi variabel yang tidak diteliti dalam penelitian ini.

Hasil penelitian ini mendukung teori yang dikemukakan Committee of Sponsoring Organization of the Tread way Commission (COSO) dalam Sawyer (2005: 144) pengendalian internal satuan usaha terdiri atas komponen-komponen berikut:

\section{a. Lingkungan pengendalian}

Inti suatu bisnis adalah orang-orangnya dengan karakteristiknya termasuk integritas, nilai-nilai, etika dan lingkungan tempat mereka bekerja. Halhal tersebut merupakan mesin penggerak perusahaan dan merupakan fondasi segala sesuatunya ditempatkan.

\section{b. Penaksiran risiko}

Perusahaan harus mewaspadai dan mengelola risiko yang dihadapinya. Perusahaan harus menetapkan tujuan yang terintegrasi dengan penjualan, produksi, pemasaran, keuangan, dan aktivitasaktivitas lainnya sehingga organisasi beroperasi secara harmonis. Perusahaan juga harus menetapkan mekanisme untuk mengidentifikasi, menganalisis, dan mengelola risiko-risiko terkait.

c. Informasi dan komunikasi

Disekitar aktivitas-aktivitas ini terdapat sistem informasi dan komunikasi. Hal ini memungkinkan karyawan perusahaan mendapatkan dan menukar informasi yang diperlukan untuk melaksanakan, mengelola, dan mengendalikan operasinya.

\section{d. Aktivitas pengendalian}

Kebijakan dan prosedur kontrol harus ditetapkan dan dilaksanakan untuk membantu memastikan bahwa tindakan-tindakan yang diidentifikasi oleh manajamen diperlukan untuk menghadapi risiko terhadap pencapaian tujuan entitas secara efektif dilakukan.

\section{e. Pemantauan}

Keseluruhan proses harus dimonitor dan dibuat perubahan bila diperlukan. Dengan cara ini, sistem dapat bereaksi secara dinamis berubah seiring dengan perubahan kondisi. Pemantauan diakukan disetiap kegiatan operasional perusahaan.

Hasil penelitian ini mendukung dengan penelitian Mariani (2011) yang berjudul "Antesedan dan Modernisasi Kualitas Pengendalian Internal terhadap Hubungan antara Keadilan organisasi dan Kinerja Karyawan yang bertujuan untuk mengetahui pengaruh masing-masing variabel independen terhadap variabel dependen menunjukkan bahwa dari variabel antesedan dan variabel modernisasi kualitas pengendalian internal yang diujikan, masing-masingnya menunjukkan adanya pengaruh terhadap keadilan organisasi dan kinerja karyawan. Kinerja karyawan lemah atau buruk terjadi lebih tinggi bila kualitas pengendalian internal dan persepsi keadilan rendah.

2. Gaya Kepemimpinan Berpengaruh terhadap Kinerja Karyawan

Hasil penelitian mendukung hipotesis kedua yaitu Gaya Kepemimpinan berpengaruh positif terhadap Kinerja karyawan SPBU Yogyakarta. Hal ini di- 


\section{Jurnal Nominal / Volume I Nomor I / Tahun 2012}

tunjukkan dari hasil analisis regresi Gaya Kepemimpinan (X2) terhadap Kinerja Karyawan (Y) diperoleh suatu persamaan regresi 1 prediktor yaitu $\mathrm{Y}=42,446+0,503 \mathrm{X} 2$ yang menyatakan jika nilai Gaya Kepemimpinan (X2) adalah nol maka nilai Kinerja Karyawan (Y) adalah sebesar 42,446 dan setiap kenaikan Gaya Kepemimpinan (X2) 1 satuan maka akan menaikkan Kinerja Karyawan (Y) sebesar 0,503 satuan, selain itu dapat juga dilihat dari nilai korelasi regresi $(\mathrm{R})$ yang bernilai positif antara Gaya Kepemimpinan (X2) dan Kinerja Karyawan (Y) sebesar 0,397. Nilai thitung lebih besar dari nilai ttabel yaitu 3,408>1,6698 dengan nilai sig 0,001 (di bawah 0,05) yang mengidentifikasikan bahwa variabel Gaya Kepemimpinan (X2) berpengaruh signifikan terhadap Kinerja Karyawan (Y). Dari hasil analisis regresi sederhana juga diperoleh nilai koefisien determinasi (R2) sebesar 0,158 yang berarti $15,8 \%$ naik turunnya nilai Kinerja Karyawan dipengaruhi oleh Gaya Kepemimpinan, sedangkan sisanya sebesar $84,2 \%$ dipengaruhi variabel yang tidak diteliti dalam penelitian ini. .

Hasil penelitian ini mendukung teori yang dikemukakan oleh Veithzal Rivai (2004: 64) Gaya kepemimpinan dapat didefenisikan sebagai perilaku dan strategi sebagai hasil kombinasi dari falsafah, keterampilan, sifat, dan sikap yang sering diterapkan seorang pemimpin ketika ia mencoba mempengaruhi kinerja bawahannya. Penelitian ini juga mendukung teori yang dikemukakan oleh Miftah Thoha (2007: 42) bahwa Teori Path Goal berusaha untuk menjelaskan pengaruh perilaku pemimpin terhadap motivasi, kepuasan, dan pelaksanaan pekerjaan bawahannya. Teori Path Goal membagi empat gaya kepemimpinan yaitu : kepemimpinan direktif, kepemimpinan supportif, kepemimpinan partisipatif, dan kepemimpinan berorientasi pada prestasi

Hasil penelitian ini sesuai dengan penelitian Niken (2010) yang menyatakan bahwa Gaya Kepemimpinan berpengaruh positif signifikan terhadap Kinerja Karyawan dan penelitian Fahmi (2009) menunjukkan ada pengaruh positif antara variabel Gaya Kepemimpinan dengan Kinerja Karyayawan. Semakin baik Gaya Kepemmpinan yang diterapkan maka akan mendorong karyawan tersebut untuk meningkatkan kinerjanya.

3. Pengendalian Internal dan Gaya Kepemimpinan Berpengaruh terhadap Kinerja Karyawan

Hasil penelitian mendukung hipotesis ketiga yaitu Pengendalian Internal dan Gaya Kepemimpinan secara bersama-sama berpengaruh positif terhadap Kinerja karyawan SPBU Yogyakarta. Hal ini ditunjukkan dari hasil analisis regresi linier berganda dengan dua prediktor Pengendalian Internal (X1) dan Gaya Kepemimpinan (X2) terhadap Kinerja Karyawan (Y) diperoleh suatu persamaan yaitu $\mathrm{Y}=$ $29,652+0,389 \mathrm{X} 1+0,354 \mathrm{X} 2$ yang menyatakan jika nilai semua variabel independen adalah sebesar nol, maka nilai $Y$ adalah sebesar 29,652. Koefisien regresi X1 sebesar 0,389 menyatakan bahwa setiap kenaikan X1 sebesar 1 satuan akan menaikkan Y sebesar 0,389 satuan jika X2 dianggap nol. Jika nilai X2 naik sebesar 1 satuan maka akan menaikkan Y sebesar 0,354 satuan jika X1 dianggap nol, selain itu dapat juga dilihat dari nilai korelasi regresi (R) yang bernilai positif antara Pengendalian Internal (X1), Gaya Kepemimpinan (X2), dan Kinerja Karyawan (Y) sebesar 0,481. Nilai Fhitung lebih besar dari nilai Ftabel yaitu $9,180>3,147$ dengan nilai sig 0,000 (di bawah 0,05 ) 


\section{Jurnal Nominal / Volume I Nomor I / Tahun 2012}

yang mengidentifikasikan bahwa variabel Pengendalian Internal (X1) dan Gaya Kepemimpinan (X2) berpengaruh signifikan secara bersama-sama terhadap Kinerja Karyawan (Y). Dari hasil analisis regresi linier berganda juga diperoleh nilai koefisien determinasi (R2) sebesar 0,231 yang berarti 23,1\% naik turunnya nilai Kinerja Karyawan dipengaruhi oleh Pengendalian Internal dan Gaya Kepemimpinan, sedangkan sisanya sebesar 76,9\% dipengaruhi variabel yang tidak diteliti dalam penelitian ini.

Hasil penelitian ini mendukung teori Dale Timple (2000) dalam Siti Munafiah (2011: 10-11) yang mengatakan bahwa terdapat dua faktor yang mempengaruhi Kinerja Karyawan yaitu faktor internal dan faktor eksternal. Faktor internal adalah faktor-faktor yang berhubungan dengan sifat-sifat seseorang meliputi sikap, sifat kepribadian, sifat fisik, motivasi, umur, jenis kelamin, pendidikan, pengalaman kinerja, latar belakang budaya, dan variabel personal lainnya. Faktor eksternal adalah faktor-faktor yang mempengaruhi kinerja karyawan yang berasal dari lingkungan meliputi kebijakan organisasi, kepemimpinan, tindakantindakan rekan kerja, pengawasan, sistem upah, dan lingkungan. Dari teori tersebut jelas gaya kepemimpinan mempengaruhi kinerja karyawan, sedangkan lingkungan, kebijakan, dan pengawasan merupakan bentuk dari pengendalian internal yang mempengaruhi kinerja karyawan.

\section{Keterbatasan Penelitian}

Penelitian ini telah dilaksanakan dan dilakukan sesuai dengan prosedur ilmiah, namun demikian masih memiliki keterbatasan yaitu:

1. Faktor-faktor yang mempengaruhi Kinerja Karyawan dalam penelitian ini hanya terdiri dari dua variabel, yaitu Pengendalian Internal dan Gaya Kepemimpinan, dengan demikian masih banyak faktor lain yang mempengaruhi Kinerja Karyawan sebesar $76,9 \%$ yang belum dikaji dalam penelitian ini.

2. Adanya keterbatasan pada teknik pengambilan data yang berupa kuesioner, sehingga peneliti tidak dapat mengontrol jawaban responden yang tidak menunjukkan keadaan yang sesungguhnya.

\section{Kesimpulan dan Saran}

\section{A. Kesimpulan}

1. Pengendalian Internal berpengaruh positif dan signifikan terhadap Kinerja Karyawan. Hal ini ditunjukkan dengan nilai korelasi regresi (R) sebesar 0,407, nilai koefisien determinasi (R2) sebesar 0,165 , dan nilai thitung 3,506 lebih besar dari nilai ttabel 1,6698 dengan nilai sig 0,001 (dibawah 0,05). Persamaan garis regresi $\mathrm{Y}=37,658+0,535$ X1 yang berarti jika Pengendalian Internal (X1) naik 1 satuan maka Kinerja Karyawan (Y) akan naik sebesar 0,535 satuan.

2. Gaya kepemimpinan berpengaruh positif dan signifikan terhadap Kinerja Karyawan. Hal ini ditunjukkan dengan nilai korelasi regresi (R) sebesar 0,397, nilai koefisien determinasi (R2) sebesar 0,158, dan nilai thitung lebih besar 3,408 dari nilai ttabel 1,6698 dengan nilai sig 0,001 (dibawah 0,05). Persamaan garis regresi $\mathrm{Y}=42,446+0,503$ X2 yang berarti jika Gaya Kepemimpinan (X2) naik 1 satuan maka Kinerja Karyawan (Y) akan naik sebesar 0,503 satuan.

3. Pengendalian Internal dan Gaya Kepemimpinan secara bersama-sama berpengaruh positif dan signifikan terhadap Kinerja Karyawan. Hal ini di- 


\section{Jurnal Nominal / Volume I Nomor I / Tahun 2012}

tunjukkan dari nilai korelasi regresi $(\mathrm{R})$ yang bernilai positif sebesar 0,481 , nilai koefisien determinasi (R2) sebesar 0,231, dan nilai Fhitung 9,180 lebih besar dari nilai Ftabel 3,147 dengan nilai sig 0,000 (dibawah 0,05). Persamaan garis regresi linier berganda dengan dua prediktor Pengendalian Internal (X1) dan Gaya Kepemimpinan (X2) terhadap Kinerja Karyawan (Y) yaitu $\mathrm{Y}=29,652+$ 0,389X1 + 0,354X2 yang menunjukan bahwa apabila nilai semua variabel independen sebesar nol, maka nilai Y sebesar 29,652. Koefisien regresi X1 sebesar 0,389 menyatakan bahwa setiap kenaikan $\mathrm{X} 1$ sebesar 1 satuan akan menaikkan $\mathrm{Y}$ sebesar 0,389 satuan jika X2 dianggap nol. Apabila nilai $\mathrm{X} 2$ naik sebesar 1 satuan maka akan menaikkan Y sebesar 0,354 satuan jika X1 dianggap nol.

4. Sumbangan relatif variabel Pengendalian Internal (X1) adalah sebesar 55,78\% dan sumbangan relatif variabel Gaya Kepemimpinan (X2) sebesar $44,22 \%$. Sementara itu, hasil perhitungan Sumbangan efektif variabel Pengendalian Internal (X1) adalah $12,9 \%$ dan sumbangan efektif variabel Gaya Kepemimpinan (X2) adalah sebesar 10,2\% masingmasing terhadap variabel Y. Secara bersama-sama variabel Pengendalian Internal (X1) dan variabel Gaya Kepemimpinan (X2) memberikan sumbangan efektif sebesar $23,1 \%$ terhadap variabel Kinerja Karyawan (Y).

\section{B. Saran}

1. Bagi Karyawan hendaknya lebih meningkatkan kinerja sesuai dengan target perusahaan

\section{Bagi Pengelola SPBU}

a. Pengelola SPBU diharapkan dapat memaksimalkan pengelolaan pengendalian internal yang sudah ada sebelumnya sehingga dapat mendorong karya- wan untuk meningkatkan kinerjanya.

b. Pimpinan hendaknya secara rutin memantau langsung kinerja karyawan dan memiliki catatan hasil pengawasan terhadap kerja karyawan.

c. Pimpinan hendaknya memberikan kesempatan bagi karyawannya untuk memberikan pendapat agar terjadi komunikasi yang baik antara pemimpin dengan seluruh karyawannya.

\section{Bagi Peneliti Selanjutnya}

a. Masih terdapat faktor-faktor lain yang berpengaruh terhadap kinerja karyawan, maka diharapkan penelitian ini dapat dilanjutkan oleh peneliti lain dengan melibatkan faktor-faktor yang belum diteliti.

b. Diharapkan pada penelitian berikutnya dapat menggunakan teknik pengumpulan data yang memberikan informasi lebih lengkap.

c. Diharapkan pada penelitian selanjutnya untuk menggunakan jenis perusahaan lain sebagai objek penelitian.

\section{E. Daftar Pustaka}

Arikunto, Suharsimi. (2006). Prosedur Penelitian Suatu Pendekatan Praktik. Jakarta: PT Asdi Mahasatya.

Bambang Hartadi. (1999). Sistem Pengendalian Internal. Yogyakarta: BPFE.

Darwito. (2008). Analisis Pengaruh Gaya Kepemimpinan Terhadap Kepuasan Kerja dan Komitmen Organisasi Untuk Meningkatkan Kinerja Karywan (Studi pada RSUD Semarang). Tesis. Magister Manajemen Program Pasca Sarjana Universitas Diponegoro. 
Depdiknas. (2008). Kamus Besar Bahasa Indonesia Edisi Keempat. Jakarta: PT. Gramedia Utama.

Eka Nuraini Rachmawati. (2004). Paradigma Baru Manajemen Sumber Daya Manusia Sebagai Basis Meraih Keunggulan Kompetitif. Yogyakarta: Ekonisia.

Fahmi. (2009). Analisis Pengaruh Gaya Kepemimpinan Dan Motivasi Kerja Terhadap Kinerja Pegawai SPBU Pandanaran Semarang. Skripsi. Universitas Gunadarma.

Griffin, Ricky. (2004). Manajemen. Jakarta: Erlangga.

Hadari Nawawi. (2006). Evaluasi dan Manajemen Kinerja di Lingkungan Perusahaan dan Industri. Yogyakarta: UGM Press.

Hani Handoko. (2003). Manajemen, Jilid 2. Yogyakarta: BPFE.

Hasibuan, Malayu S.P. (2003). Manajemen Sumber Daya Manusia. Jakarta: Bumi Aksara

Imam Ghozali. (2009). Aplikasi Analisis Multivariat Dengan Program SPSS. Semarang: UNDIP.

Mariani. (2011). Anteseden dan Moderasi Kualitas Pengendalian Internal terhadap Hubungan antara Keadilan Organisasi dan Kinerja Karyawan (Studi Kasus Pada Pemerintah Kabupaten Semarang). Skripsi. Fakultas Ekonomi. Universitas Diponegoro Semarang.

Miftah Thoha. (2007). Kepemminan Dalam Manajemen. Jakarta: PT RajaGrafindo Persada

Muhammad Zainur Roziqin. (2010). Kepuasan Kerja. Malang: Averroes Press.

Mulyadi. (2001). Sistem Akuntansi. Jakarta: Salemba Empat. . (2002). Auditing. Jakarta: Salemba Em-

pat

Niken Puspitasari. (2010). Pengaruh Motivasi dan Gaya Kepemimpinan terhadap Kinerja Karyawan pada PT Adi Satria Abadi Yogyakarta. Skripsi. FISE Universitas Negeri Yogyakarta.

Nur Indriantoro dan Bambang Supomo. (2009). Metode Penelitian Bisnis. Yogyakarta: BPFE.

Nurjanah. (2008). Pengaruh Gaya Kepemimpinan dan Budaya Organisasi terhadap Komitmen Organisasi Dalam Meningkatkan Kinerja Karyawan (Studi pada Biro Lingkup Departemen Pertanian). Tesis. Magister Manajemen Program Pasca Sarjana Universitas Diponegoro.

Pabundu Tika. (2006). Budaya Organisasi Dan Peningkatan Kinerja Perusahan. Jakarta: Bumi Aksara.

Sawyer. (2005). Internal Auditing. Jakarta: Salemba Empat.

Siti Aisah. (2010). Pengaruh Pengendalian Intern, Kepatuhan, dan Integritas Manajemen terhadap Perilaku Etis Karyawan Dalam Sistem Pengajian. Skripsi. Universitas Pembangunan Nasional "Veteran".

Siti Munafiah. (2011). Pengaruh Kompensasi dan Supervisi terhadap Kinerja Karyawan (Studi Kasus pada PT. Industri Sandang Nusantara Unit Patal Secang). Skripsi. FE Universitas Negeri Yogyakarta.

Sugiyono. (2009). Metode Penelitian Kuantitatif Kualitatif dan R\&D. Bandung: ALFABETA.

Sutrisno Hadi. (2004). Analisis Regresi. Yogyakarta : Andi Offset

Suyadi Prawirosentono. (2008). Manajemen Sum- 
berdaya Manusia Kebijakan Kinerja Karyawan. Wilopo. (2006). “Analisis Faktor-Faktor Yang BerYogyakarta: BPFE. pengaruh Terhadap Kecenderungan Kecurangan

Tim Penyusun Jurusan Akuntansi. (2011). PeAkuntansi: Studi Pada Perusahaan Publik dan Badoman Penulisan Tugas Akhir Jurusan Pendidikan Akuntansi. Yogyakarta: Universitas Negeri Yogyakarta. dan Usaha Milik Negara Di Indonesia.” Proceeding Simposium Nasional Akuntansi IX Padang. 23-26 Agustus 2006.

Veitzhal Rivai. (2004). Kepemimpinan Dan Perilaku Organisasi. Jakarta: PT.Raja

Grafindo.

Widyatmini dan Luqman Hakim. (2008) (2006). “Analisis Faktor-Faktor Yang Berpengaruh Terhadap Kecenderungan Kecurangan Akuntansi: Studi Pada Perusahaan Publik dan Badan Usaha Milik Negara Di Indonesia.” Jurnal "Hubungan Kepemimpinan, Kompensasi, Dan Riset Akuntansi Indonesia. Vol. 9, No. 3: Hal. 346Kompetensi Terhadap Kinerja Pegawai Dinas Kesehatan Kota Depok.” Jurnal Ekonomi Bisnis. No. 2 Vol 13, Agustus 2008. 366.

Wirawan. (2009). Evaluasi Kinerja Sumber Daya Manusia. Jakarta: Salemba Empat 